\title{
Blood transfusion service in Poland in 2018
}

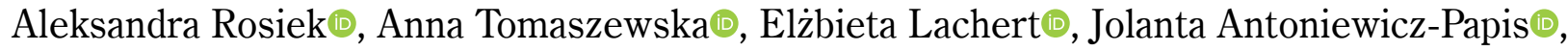 \\ Jolanta Kubis@, Ryszard Pogłód®, Magdalena Łętowska®
}

Department of Transfusion Medicine, Institute of Hematology and Transfusion Medicine in Warsaw

\section{Summary}

Background: Assessment of the basic aspects of the activity of the Polish Regional Blood Transfusion Centers (hereinafter referred to as Centers) in 2018.

Materials and methods: Retrospective analysis of the 2018-data supplied by the Centers.

Results: In 2018, blood and blood components were collected in 21 Centers and 132 local collection sites as well as during 13189 mobile collections. The overall number of blood donors was estimated at 590 470; the majority were non-remunerated donors (589 897 — including 37824 responders to donation appeals), 73 remunerated donors and 500 autologous donors. Most frequent were whole blood collections (1 184 311), least frequent - granulocyte concentrate collections (116) and red blood cell (RBC) collection by apheresis (31 donations). Whole blood was collected mostly in local collection sites (44.85\%), less frequently in Centers (28.47\%) and at mobile collection sites (26.67\%). Most frequently prepared blood components were RBC - 1161600 units) and fresh frozen plasma (FFP - 1298216 units; 20.93\% dedicated for clinical use). Platelet concentrates (PCs) collected by apheresis amounted to 50255 units and 83598 were whole blood-derived.

Additional processing methods such as leukocyte depletion and irradiation were more frequently applied to PCs (32.56\% leukocyte depleted, $1.37 \%$ irradiated, $58.07 \%$ both leukocyte depleted and irradiated) than to RBCs (17.29\% leukocyte depleted, $0.31 \%$ irradiated, $8.94 \%$ both leukocyte depleted and irradiated). Pathogen reduction technologies were applied to $11.74 \%$ of PCs and $10.23 \%$ units of FFP issued for transfusion.

In 2018 - for various reasons - 14067 units of whole blood, 30521 units of RBC, 49979 units of FFP, 1376 units of cryoprecipitate, 5186 units of pooled PCs and 1625 of apheresis PCs were wasted.

Conclusions: The study data may contribute to evaluation of the tendencies observed in Centers and may serve practical-benchmarking which in turn may prove beneficial to the transfusion community as a whole.

\section{Key words: blood donors, blood donation, blood components}

J. Transf. Med. 2019; 12: 144-159

\section{Introduction}

This is the eleventh presentation of the selected issues related to the annual activity of public blood transfusion service (BTS) in Poland. Of particular interest were 2018 - data referring to the following issues: number of donors, donations, collection sites for whole blood and blood components, including RBC, fresh frozen plasma (FFP), platelet cell concentrate $(\mathrm{PC})$ and granulocyte con- 
centrate (GC). Discussed were also issues related to administration of additional preparation methods as well as inactivation of biological pathogens in labile blood components. The most common causes of blood component wastage as well as the scale of the phenomenon were also explored.

The activity of Polish BTS is regulated by the Public Blood Transfusion Service Act voted by the Polish Parliament in 1997 [1]. Pursuant to this Act, blood is collected in public Centers exclusively, no private collection Centers are permitted. There are 21 Centers as well as the Military Blood Transfusion Center (supervised by the Ministry of Defense) and the Blood Transfusion Center of the Ministry of Internal Affairs and Administration. The activity of BTS in Poland is supervised by the Polish Ministry of Health and the Institute of Hematology and Transfusion Medicine (IHTM) exercises supervision over the activity of all Centers.

\section{Materials and methods}

As in the previous years, this study relies on data provided by 21 Centers in form of annual reports. With the aim of standardization of the forwarded data, IHTM together with the National Blood Centre (NCK) created a template of definitions.

First-time donor - donates blood during the reporting period but has never before donated blood for medical purposes.

Multiple (regular) donor - systematically donates blood (at least twice during the last 24 months). Multiple repeat donor - donates blood again more than 2 years after the last donation.

Non remunerated donor - receives no financial compensation for donated blood/blood component at least once during the reporting period.

Remunerated donor - receives financial compensation for every donation during the reporting period.

Responder to donation appeal — donates blood /blood component following emergency appeal for donation at least once during the reporting period (the term also applies to former ,family donors"). Directed donor - donates blood for a specific patient at least once during the reporting period. Autologous donor - donates blood/blood component for himself at least once during the reporting period. Donation - whole blood or blood component collected by apheresis, including blood for clinical and scientific purposes collected from immunized and family donors etc.

Unit (u.) - volume of anticoagulated whole blood obtained from $450 \mathrm{ml}$ of blood collected from the donor or volume of blood component obtained from one unit of anticoagulated whole blood.

Unit of plasma - volume of plasma obtained from whole blood or by automated plasmapheresis. One automated plasmapheresis procedure provides 3 units of plasma $(600 \mathrm{ml})$.

Unit of PC from apheresis - platelets obtained from a single donor with cell separator (1 donation regardless of platelet count).

Therapeutic dose of PC - PCs (either pooled or from apheresis) dedicated for an adult; according to current guidelines it contains $\geq 3 \times 10^{11}$ platelets.

\section{Results}

\section{Regional Blood Transfusion Centers (Centers)}

In 2018 there were 21 Centers and 132 local collection sites operating in Poland, which is one local collection site less than in 2017. As in the previous year, 13189 mobile collections were performed. In 2018 all Centers organized mobile collection sites and — just as in 2017 — the largest number of mobile collections was organized by the Center in Katowice (1949). More than 1000 mobile collections were organized in Łódź (1197), Wałbrzych (1269) and Warsaw (1243). As compared to the previous year, the number of mobile collections increased in 12 Centers and the upward trend was most evident for Szczecin ( a $7.59 \%$ increase) (Table 1).

\section{Donors}

In 2018, a total of 693772 persons came to donate blood (in $2017-692$ 181). Only 590 470 of them were qualified (in $2017-588184$ ). It follows that - as in the previous years - approximately $85 \%$ of people who were willing to donate blood were qualified for donation of blood or blood components for clinical use. The difference was mostly due to donor deferral. In 2018, a total of 9147 permanent deferrals were applied as well as 226542 temporary deferrals of 187747 persons; as in previous years, the most frequent cause for deferral (75 099) was low hemoglobin level.

Donors were mostly non-remunerated (589 897 - 37824 responders to appeal and 64 directed donors). In 2018, blood and blood components were also donated by 73 remunerated donors and 500 autologous donors.

In 11 Centers blood was donated only by non-remunerated donors. The highest number of remunerated donors (27) was reported by Center in Poznań. 
Table 1. Mobile collections organized in Polish Regional Blood Transfusion Centers (2017-2018)

\begin{tabular}{|c|c|c|c|}
\hline \multirow[t]{2}{*}{ Centers } & \multicolumn{3}{|c|}{ Mobile collections } \\
\hline & 2017 & 2018 & $\begin{array}{c}\text { Increase/ } \\
\text { /decrease as } \\
\text { compared to } \\
2017\end{array}$ \\
\hline Białystok & 730 & 729 & $\downarrow$ \\
\hline Bydgoszcz & 806 & 816 & $\uparrow$ \\
\hline Gdańsk & 523 & 432 & $\downarrow$ \\
\hline Kalisz & 395 & 416 & $\uparrow$ \\
\hline Katowice & 1959 & 1949 & $\downarrow$ \\
\hline Kielce & 292 & 285 & $\downarrow$ \\
\hline Kraków & 796 & 833 & $\uparrow$ \\
\hline Lublin & 321 & 337 & $\uparrow$ \\
\hline Łódź & 1273 & 1197 & $\downarrow$ \\
\hline Olsztyn & 510 & 507 & $\downarrow$ \\
\hline Opole & 315 & 271 & $\downarrow$ \\
\hline Poznań & 816 & 851 & $\uparrow$ \\
\hline Racibórz & 235 & 250 & $\uparrow$ \\
\hline Radom & 342 & 325 & $\downarrow$ \\
\hline Rzeszów & 228 & 240 & $\uparrow$ \\
\hline Słupsk & 161 & 164 & $\uparrow$ \\
\hline Szczecin & 369 & 397 & $\uparrow$ \\
\hline Wałbrzych & 1299 & 1269 & $\downarrow$ \\
\hline Warszawa & 1168 & 1243 & $\uparrow$ \\
\hline Wrocław & 369 & 383 & $\uparrow$ \\
\hline Zielona Góra & 282 & 295 & $\uparrow$ \\
\hline Total & 13189 & 13189 & No change \\
\hline
\end{tabular}

In 2018 there were 140813 first-time donors (23.85\%), $368748(62.45 \%)$ multiple regular donors and 80909 (13.70\%) multiple repeat donors.

10 Centers reported a decrease in the number of donors while 11 noted an increase. As compared to 2017, the highest increase was observed in Centers in Lublin (by 10.67\%) and Warsaw (by $6.44 \%$ ). Table 2 presents the number of donors in each Center in 2018.

As in the previous years, the largest group of donors were aged 18-44 (514 093; 147218 women and 366875 men).

\section{Donations}

In 2018, whole blood was collected most frequently (1 184311 donations), while the least frequent were collections of granulocytic concentrate (116 donations in 6 Centers) and RBC from apheresis ( 31 donations in 2 Centers). As in previous years, the largest number of whole blood donations was reported by Center in Katowice (113 983) and in Warsaw (108 658). Apheresis was mainly used for preparation of PC (24 587 donations) and plasma (36 655 donations). The largest number of apheresis plasma donations was reported by Center in Kalisz (8116) and Center in Warsaw performed the largest number of apheresis PC donations (8031).

Automated donations of a combination of blood components were also performed usually $\mathrm{PC}$ and plasma (19 143), less often PC and RBC (60).

Table 3 presents the number of complete donations of blood and blood components in 2018.

Blood was collected primarily in local collection sites (44.85\% of whole blood donations), less often in Center (28.47\%) as well as during mobile collections $(26.67 \%)$. As in the previous years, most of the whole blood (59.72\%) was collected during mobile collections organized by Center in Wałbrzych. Table 4 provides a list of whole blood donation sites in 2018.

\section{Blood components}

\section{Red Blood cells (RBCs)}

Donated blood was processed into blood components, mostly RBC (1 161600 units), which represented a slight increase country-wide as compared to the previous year (1 154239 units). As in previous years, the majority of RBC were obtained in Centers in Katowice and Warsaw (112 735 and 108332 units respectively) (Table 5). The largest increase in the number of $\mathrm{RBC}$ was recorded in Lublin (by 10.83\%) and in Warsaw (by $5.34 \%)$. A decrease was reported by 10 Centers and an increase by 11 .

Some RBC were subjected to additional preparation - mostly leukocyte reduction and irradiation.

In 2018, a total of 200792 units of leukocyte depleted RBC was obtained (17.29\% of all RBC), 3579 units of irradiated RBC $-0.31 \%$. In many cases leukocyte reduction and irradiation were used in combination to obtain 103886 units of both leukoreduced and irradiated RBC $-8.94 \%$ of all red cell units.

Country-wide, $26.23 \%$ of all RBC $(20.70 \%$ in 2017) were subjected to leukocyte reduction and $9.25 \%$ to irradiation $(8.46 \%$ - in 2017). Table 6 presents the number of irradiated RBC units and leukocyte depleted $\mathrm{RBC}$ obtained by each Center in 2018 . 
Table 2. Blood donors in Polish Regional Blood Transfusion Centers (2018)

\begin{tabular}{|c|c|c|c|c|c|}
\hline \multirow{2}{*}{ Centers } & \multicolumn{4}{|l|}{ Donors } & \multirow{2}{*}{$\begin{array}{l}\text { Increase/decrease as } \\
\text { compared to } 2017\end{array}$} \\
\hline & First-time & Multiple regular & Multiple repeat & Total & \\
\hline Białystok & 5193 & 20871 & 3455 & 29519 & $\downarrow$ \\
\hline Bydgoszcz & 8361 & 22332 & 4375 & 35068 & $\uparrow$ \\
\hline Gdańsk & 6375 & 18324 & 3722 & 28421 & $\downarrow$ \\
\hline Kalisz & 4440 & 13680 & 2493 & 20613 & $\uparrow$ \\
\hline Katowice & 10389 & 34076 & 6108 & 50573 & $\downarrow$ \\
\hline Kielce & 5475 & 10191 & 2709 & 18375 & $\uparrow$ \\
\hline Kraków & 10656 & 28495 & 5629 & 44780 & $\uparrow$ \\
\hline Lublin & 7496 & 16355 & 3988 & 27839 & $\uparrow$ \\
\hline Łódź & 10253 & 18726 & 5957 & 34936 & $\downarrow$ \\
\hline Olsztyn & 4962 & 10728 & 5170 & 20860 & $\uparrow$ \\
\hline Opole & 3043 & 8638 & 1861 & 13542 & $\downarrow$ \\
\hline Poznań & 10423 & 31236 & 6499 & 48158 & $\downarrow$ \\
\hline Racibórz & 2293 & 10153 & 1745 & 14191 & $\downarrow$ \\
\hline Radom & 3312 & 6566 & 1814 & 11692 & $\uparrow$ \\
\hline Rzeszów & 5745 & 20295 & 3199 & 29239 & $\uparrow$ \\
\hline Słupsk & 3160 & 6662 & 1212 & 11034 & $\downarrow$ \\
\hline Szczecin & 6164 & 15603 & 3030 & 24797 & $\downarrow$ \\
\hline Wałbrzych & 2621 & 8013 & 1243 & 11877 & $\downarrow$ \\
\hline Warszawa & 17344 & 34258 & 9342 & 60944 & $\uparrow$ \\
\hline Wrocław & 9571 & 23696 & 5451 & 38718 & $\uparrow$ \\
\hline Zielona Góra & 3537 & 9850 & 1907 & 15294 & $\downarrow$ \\
\hline Total & 140813 & 368748 & 80909 & 590470 & $\uparrow$ \\
\hline
\end{tabular}

$\downarrow$ - decrease as compared to 2017

$\uparrow$ - increase as compared to 2017

\section{Platelet concentrate}

Platelet concentrate $(\mathrm{PC})$ was the second most frequently prepared blood component, just like in the years before. Two basic methods were used for $\mathrm{PC}$ preparation:

- centrifugation of whole blood from traditional donations, and - if necessary - pooling of several units of the PC to obtain pooled PC. In some Centers automated methods were used;

- apheresis with cell separators (some of the PC units obtained with this method were divided into smaller therapeutic doses).

In 2018, a total of 83598 pooled PC units were prepared (in 2017 - 77671 ), including 53369 from buffy coat with manual method and 30228 with automated methods. A total of 50255 PCs (37.54\%) were obtained by apheresis (in $2017-39.86 \%$ ).

As in previous years, the largest volume of whole blood PCs was obtained in Poznań (11 547 pooled PC units), and of apheresis PCs in Warsaw (13 311).
The percentage of PCs from apheresis differed significantly between Centers and ranged from $0.95 \%$ in Zielona Góra to $77.72 \%$ in Warsaw and $70.73 \%$ in Wrocław (Table 7).

Some part of the PC units were subjected to leukocyte depletion and/or irradiation. PCs collected by apheresis with modern cell separators are usually leukocyte depleted and require no additional leukocyte depletion.

In 2018, a total of 43589 therapeutic doses of leukocyte-reduced PCs were obtained, which was $32.56 \%$ of the total PCs obtained and 1834 therapeutic doses of irradiated PCs (1.37\%). Leukocyte reduction and irradiation were often used in combination to obtain 77734 therapeutic doses of both leukocyte depleted and irradiated PCs (58.07\%).

Country-wide, a total of $90.64 \%$ of all PC therapeutic doses were leukocyte depleted and $59.44 \%$ were irradiated (in $2017-92.07 \%$ and $57.60 \%$ respectively). 
Table 3. Whole blood and apheresis donations in 2018

\begin{tabular}{|c|c|c|c|c|c|c|c|c|}
\hline \multirow[t]{2}{*}{ Centers } & \multirow{2}{*}{$\begin{array}{l}\text { Wholeb- } \\
\text { lood }\end{array}$} & \multicolumn{6}{|c|}{ Apheresis } & \multirow[t]{2}{*}{ Total } \\
\hline & & Plasma & RBC & PC & GC & PC+plasma & $\mathrm{PC}+\mathrm{RBC}$ & \\
\hline Białystok & 60817 & 5514 & 0 & 153 & 44 & 1244 & 0 & 67772 \\
\hline Bydgoszcz & 69619 & 3823 & 0 & 927 & 27 & 0 & 0 & 74396 \\
\hline Gdańsk & 60078 & 1274 & 0 & 531 & 0 & 0 & 0 & 61883 \\
\hline Kalisz & 40793 & 8116 & 0 & 377 & 0 & 415 & 0 & 49701 \\
\hline Katowice & 113983 & 53 & 0 & 5259 & 0 & 4578 & 0 & 123873 \\
\hline Kielce & 33213 & 663 & 0 & 640 & 0 & 0 & 0 & 34516 \\
\hline Kraków & 91429 & 32 & 0 & 2065 & 27 & 0 & 0 & 93553 \\
\hline Lublin & 55141 & 3194 & 0 & 1381 & 0 & 0 & 0 & 59716 \\
\hline Łódź & 60772 & 106 & 0 & 672 & 0 & 0 & 0 & 61550 \\
\hline Olsztyn & 42885 & 1031 & 0 & 7 & 0 & 560 & 0 & 44483 \\
\hline Opole & 28808 & 46 & 0 & 401 & 0 & 0 & 0 & 29255 \\
\hline Poznań & 94843 & 2471 & 0 & 1043 & 0 & 660 & 0 & 99017 \\
\hline Racibórz & 32245 & 1601 & 0 & 0 & 0 & 372 & 0 & 34218 \\
\hline Radom & 22176 & 1084 & 0 & 52 & 0 & 583 & 0 & 23895 \\
\hline Rzeszów & 63621 & 2083 & 0 & 1159 & 0 & 0 & 0 & 66863 \\
\hline Słupsk & 23058 & 175 & 0 & 225 & 0 & 142 & 14 & 23614 \\
\hline Szczecin & 50969 & 610 & 0 & 30 & 3 & 2485 & 0 & 54097 \\
\hline Wałbrzych & 26078 & 0 & 25 & 89 & 0 & 0 & 25 & 26217 \\
\hline Warszawa & 108658 & 83 & 0 & 8031 & 5 & 3245 & 0 & 120022 \\
\hline Wrocław & 72602 & 4670 & 6 & 1520 & 10 & 4834 & 21 & 83663 \\
\hline Zielona Góra & 32523 & 26 & 0 & 25 & 0 & 25 & 0 & 32599 \\
\hline Total & 1184311 & 36655 & 31 & 24587 & 116 & 19143 & 60 & 1264903 \\
\hline
\end{tabular}

*Complete donations only

Table 8. presents the numbers of leukocyte depleted and irradiated PCs obtained by each Center in 2018.

In 2018 a total of 126786 therapeutic doses of PC were issued for clinical use (in 2015 - 113984 , in 2016 - 118153 and in 2017 - 123 443), the upward trend is therefore evident.

Some PCs were stored frozen.

In 2018, $3.7 \%$ of all PCs were subjected to freezing (including $3.8 \%$ pooled $\mathrm{PCs}, 3.6 \% \mathrm{PCs}$ from apheresis). For the last several years the percentage of frozen PCs is observed to decrease; as compared to 2017 by $0.9 \%$. However, in consecutive years the percentage of frozen PCs in individual Centers is on the same level despite recommendations for the number to be to reduced. The percentage differs between Centers and ranges from $0 \%$ in Kalisz and Poznań to $18.7 \%$ in Slupsk (increase by $0.6 \%$ as compared to 2017 ), $24.3 \%$ in Opole (decrease by $2.0 \%$ ), $32.2 \%$ in Radom (in- crease by $0.4 \%$ ), $43.7 \%$ in Wałbrzych (decrease by $6.5 \%$ ), and as much as $60.0 \%$ in Raciborz (increase by $0.8 \%$ ). As in 2017 , Raciborz reported the largest percentage of frozen pooled PCs $(75.2 \%)$.

In 2018, thawed PCs were $3.7 \%$ of all PC therapeutic units issued for clinical use, i.e. $0.4 \%$ less than in 2017. The largest number of thawed PC units was issued by Racibórz (79.0\% of all PC units issued for clinical use), Wałbrzych (41.0\%), Radom (35.7\%), Opole (24.0\%) and Slupsk (18.9\%). The Centers in Racibórz and Slupsk reported a marked decrease as compared to 2017 (by $9.6 \%$ and $11.3 \%$ respectively).

\section{Fresh frozen plasma}

In 2018, a total of 1298216 units of FFP were prepared (in 2017 - 1287001 units). As in the previous years, FFP was mainly obtained by manual method, i.e. plasma obtained from anticoagulated whole blood. With this method, 1154958 FFP 
Table 4. Sites of whole blood collection in 2018*

\begin{tabular}{|c|c|c|c|c|c|c|c|}
\hline \multirow[t]{3}{*}{ Centers } & \multicolumn{7}{|c|}{ Whole blood collected (units and percentage) } \\
\hline & \multicolumn{2}{|c|}{ Center site } & \multicolumn{2}{|c|}{ Local collection site } & \multicolumn{2}{|c|}{ Mobile collection site } & \multirow{2}{*}{$\begin{array}{c}\text { Total } \\
\text { U. }\end{array}$} \\
\hline & $\mathrm{U}$. & $\%$ & U. & $\%$ & $\mathrm{U}$. & $\%$ & \\
\hline Białystok & 24660 & 40.25 & 17460 & 28.50 & 19140 & 31.24 & 61260 \\
\hline Bydgoszcz & 17168 & 24.47 & 26458 & 37.71 & 26538 & 37.82 & 70164 \\
\hline Gdańsk & 18838 & 31.14 & 31465 & 52.02 & 10185 & 16.84 & 60488 \\
\hline Kalisz & 7923 & 19.34 & 17208 & 42.00 & 15841 & 38.66 & 40972 \\
\hline Katowice & 13794 & 11.95 & 63085 & 54.66 & 38529 & 33.39 & 115408 \\
\hline Kielce & 15009 & 44.91 & 10376 & 31.04 & 8038 & 24.05 & 33423 \\
\hline Kraków & 22784 & 24.77 & 48123 & 52.32 & 21072 & 22.91 & 91979 \\
\hline Lublin & 15868 & 28.49 & 31703 & 56.92 & 8126 & 14.59 & 55697 \\
\hline Łódź & 16026 & 26.02 & 22102 & 35.89 & 23455 & 38.09 & 61583 \\
\hline Olsztyn & 12023 & 27.66 & 19158 & 44.07 & 12289 & 28.27 & 43470 \\
\hline Opole & 6353 & 21.97 & 16634 & 57.53 & 5929 & 20.50 & 28916 \\
\hline Poznań & 26146 & 27.14 & 43963 & 45.64 & 26213 & 27.21 & 96322 \\
\hline Racibórz & 4132 & 12.72 & 21552 & 66.35 & 6797 & 20.93 & 32481 \\
\hline Radom & 11188 & 50.24 & 3511 & 15.77 & 7568 & 33.99 & 22267 \\
\hline Rzeszów & 15980 & 24.92 & 42202 & 65.82 & 5933 & 9.25 & 64115 \\
\hline Słupsk & 9892 & 44.56 & 8529 & 38.42 & 3777 & 17.02 & 22198 \\
\hline Szczecin & 22332 & 43.60 & 18796 & 36.70 & 10090 & 19.70 & 51218 \\
\hline Wałbrzych & 10611 & 40.28 & 0 & 0.00 & 15731 & 59.72 & 26342 \\
\hline Warszawa & 26382 & 23.94 & 50461 & 45.80 & 33338 & 30.26 & 110181 \\
\hline Wrocław & 34830 & 47.36 & 26693 & 36.30 & 12018 & 16.34 & 73541 \\
\hline Ziel. Góra & 8287 & 25.25 & 16425 & 50.04 & 8113 & 24.72 & 32825 \\
\hline Total & 340226 & 28.47 & 535904 & 44.85 & 318720 & 26.67 & 1194850 \\
\hline
\end{tabular}

*Incomplete donations included

units were obtained in 2018. With the less frequent method of apheresis 143258 units were obtained (11.04\% of all FFP units) as compared to 2017 140309 units - 10.90\%). The percentage of FFP obtained by apheresis varied between Centers and ranged from $0 \%$ in Wałbrzych to $38.31 \%$ in Kalisz.

Table 9. presents the number of FFP units obtained by manual method and by apheresis in individual Centers in 2018.

A total of 271702 FFP units were issued for clinical purposes (20.93\% of all plasma collected), i.e. slightly less than in 2017 (291989 FFP units, i.e. $22.69 \%)$. In individual Centers, the percentage of FFP issued for clinical purposes ranged from $6.82 \%$ in Center in Kalisz to $40.48 \%$ in Warsaw (Table 10).

\section{Granulocyte concentrate}

As in previous years, granulocyte concentrate (GC) was sporadically obtained (116 donations), however an increase was reported as compared to 2017 (50 donations). The number of Centers in which GC was collected also increased (in 2018 -6 , in $2017-4$ ). The largest numbers of GC donations were reported for Białystok (44) and Krakow (27).

\section{Quarantine and inactivation of biological pathogens in labile blood components}

In Poland, for strengthening the safety of transfused blood components we rely solely on quarantine ${ }^{1}$ or pathogen inactivated FFP and cryoprecipitate. In vitro studies as well as multicenter clinical trials have also proved that some methods of pathogen inactivation (Mirasol PRT with ribofla- 
Table 5. Units of RBCs prepared in Polish Regional Blood Transfusion Centers in 2018

\begin{tabular}{|c|c|c|}
\hline Centers & RBCs & $\begin{array}{c}\text { Increase/decrease as } \\
\text { compared to } 2017\end{array}$ \\
\hline Białystok & 59416 & $\downarrow$ \\
\hline Bydgoszcz & 69569 & $\uparrow$ \\
\hline Gdańsk & 59683 & $\downarrow$ \\
\hline Kalisz & 39318 & $\downarrow$ \\
\hline Katowice & 112735 & $\uparrow$ \\
\hline Kielce & 33131 & $\uparrow$ \\
\hline Kraków & 91226 & $\downarrow$ \\
\hline Lublin & 55039 & $\uparrow \uparrow$ \\
\hline Łódź & 60633 & $\downarrow$ \\
\hline Olsztyn & 42796 & $\uparrow$ \\
\hline Opole & 28782 & $\uparrow$ \\
\hline Poznań & 91450 & $\uparrow$ \\
\hline Racibórz & 31606 & $\downarrow$ \\
\hline Radom & 21889 & $\uparrow$ \\
\hline Rzeszów & 60768 & $\uparrow$ \\
\hline Słupsk & 21979 & $\downarrow$ \\
\hline Szczecin & 50955 & $\downarrow$ \\
\hline Wałbrzych & 26078 & $\downarrow$ \\
\hline Warszawa & 108332 & $\uparrow \uparrow$ \\
\hline Wrocław & 63774 & $\uparrow$ \\
\hline Zielona Góra & 32441 & $\downarrow$ \\
\hline Total & 1161600 & $\uparrow$ \\
\hline
\end{tabular}

$\downarrow$ - decrease as compared to 2017

$\uparrow$ - increase by $0.1-5.0 \%$ as compared to 2017

$\uparrow \uparrow$ - increase by $>5.0 \%$ as compared to 2017

vin, Intercept with amotosalen hydrochloride) do not only reduce the risk of pathogen transmission but may be an alternative to irradiation applied for prevention against Transfusion-Associated Graft Versus Host Disease, TA-GvHD)] [2-4].

In 2018, 12 Centers subjected to pathogen reduction technology (PRT) from $0.09 \%$ (Lublin) to $22.52 \%$ (Poznań) of plasma from whole blood or collected by automated plasmapheresis. The highest percentage of pathogen inactivated plasma was reported in Poznan $(22.52 \%$ - Theraflex MB Plasma system), in Warsaw $(10.18 \%$; 9.94\% inactivated with Mirasol system, $0.24 \%$ with Intercept system) and in Katowice $(10.00 \%$ with Mirasol system). In the remaining Centers the percentage of pathogen inactivated plasma did not exceed $6 \%$ and ranged from $0.09 \%$ in Lublin to 5.15 in Kraków.
Table 6. Leukocyte-depleted and irradiated RBCs produced in Polish Regional Blood Centers (2018)

\begin{tabular}{lccc}
\hline Centers & $\begin{array}{c}\text { Units of } \\
\text { leukocyte- } \\
\text {-depleted } \\
\text { RBCs }\end{array}$ & $\begin{array}{c}\text { Units of } \\
\text { irradiated } \\
\text { RBCs }\end{array}$ & $\begin{array}{c}\text { Units of both } \\
\text { irradiated } \\
\text { and leuko- } \\
\text { cyte-deplet- } \\
\text { ed RBCs }\end{array}$ \\
\hline Białystok & 1961 & 0 & 5543 \\
Bydgoszcz & 3229 & 0 & 9584 \\
Gdańsk & 1440 & 1 & 14080 \\
Kalisz & 10563 & 0 & 0 \\
Katowice & 28729 & 1839 & 6721 \\
Kielce & 5804 & 0 & 2722 \\
Kraków & 6307 & 620 & 7342 \\
Lublin & 0 & 516 & 8852 \\
tódź & 13215 & 40 & 9885 \\
Olsztyn & 4618 & 7 & 4078 \\
Opole & 3927 & 0 & 464 \\
Poznań & 14021 & 7 & 7999 \\
Racibórz & 3622 & 0 & 20 \\
Radom & 1723 & 0 & 178 \\
Rzeszów & 135 & 65 & 7836 \\
Słupsk & 968 & 0 & 1544 \\
Szczecin & 954 & 465 & 917 \\
Wałbrzych & 309 & 0 & 0 \\
Warszawa & 87754 & 0 & 7150 \\
Wrocław & 5266 & 19 & 6766 \\
Zielona Góra & 6247 & 0 & 2205 \\
Total & 200792 & 3579 & 103886 \\
\hline & & & \\
\hline
\end{tabular}

In $2018,89.71 \%$ of quarantine FFP and $81.48 \%$ of cryoprecipitate units were issued for clinical use, as well as $10.23 \%$ of pathogen inactivated FFP and $18.52 \%$ of cryoprecipitate (cryoprecipitate only in Poznań and Łódź).

In 5 Centers the system of pathogen inactivation for PCs was implemented. The highest percentage of PCs subjected to pathogen inactivation was reported for Warsaw $(99.34 \%$ of pooled leukocyte depleted PCs and $47.85 \%$ of leukocyte depleted PCs from apheresis). Center in Łódź pathogen inactivated (with Mirasol system) only $0.37 \%$ of leukocyte depleted PCs from apheresis (12.8\% - in 2017). In 2018, no pathogen inactivation was applied to PCs in the Center in Kielce although in the same Center in 2017 13.6\% of leukocyte depleted apheresis $\mathrm{PCs}$ were subjected to pathogen inactivation. In 
Table 7. PCs (from apheresis and whole blood) prepared in Polish Regional Blood Transfusion Centers (2018)

\begin{tabular}{|c|c|c|c|c|}
\hline \multirow[t]{2}{*}{ Centers } & \multicolumn{4}{|c|}{ PCs (therapeutic doses) } \\
\hline & Pooled from whole blood & Apheresis & Total & $\%$ apheresis PCs \\
\hline Białystok & 1349 & 2784 & 4133 & 67.36 \\
\hline Bydgoszcz & 7916 & 1147 & 9063 & 12.66 \\
\hline Gdańsk & 5387 & 815 & 6202 & 13.14 \\
\hline Kalisz & 1773 & 522 & 2295 & 22.75 \\
\hline Katowice & 9733 & 7395 & 17128 & 43.17 \\
\hline Kielce & 3415 & 701 & 4116 & 17.03 \\
\hline Kraków & 6621 & 2570 & 9191 & 27.96 \\
\hline Lublin & 4055 & 1666 & 5721 & 29.12 \\
\hline Łódź & 4616 & 804 & 5420 & 14.83 \\
\hline Olsztyn & 3795 & 695 & 4490 & 15.48 \\
\hline Opole & 1169 & 401 & 1570 & 25.54 \\
\hline Poznań & 11547 & 3080 & 14627 & 21.06 \\
\hline Racibórz & 966 & 391 & 1357 & 28.81 \\
\hline Radom & 821 & 678 & 1499 & 45.23 \\
\hline Rzeszów & 5963 & 1240 & 7203 & 17.22 \\
\hline Słupsk & 848 & 302 & 1150 & 26.26 \\
\hline Szczecin & 2324 & 2678 & 5002 & 53.54 \\
\hline Wałbrzych & 1085 & 119 & 1204 & 9.88 \\
\hline Warszawa & 3816 & 13311 & 17126 & 77.72 \\
\hline Wrocław & 3695 & 8930 & 12625 & 70.73 \\
\hline Zielona Góra & 2704 & 26 & 2730 & 0.95 \\
\hline Total & 83598 & 50255 & 133853 & 37.54 \\
\hline
\end{tabular}

Centers in Lublin and Łódź the percentage of inactivated leukocyte depleted apheresis PCs did not exceed $1 \%(0.71 \%$ and $0.37 \%$ respectively). In Katowice only trace volumes were subjected to inactivation $(0.01 \%$ of pooled leukocyte depleted PCs and $0.02 \%$ of leukocyte depleted apheresis PCs).

In 2018, country-wide statistics reported a total of $11.74 \%$ of inactivated PC therapeutic units (in $2017-11.41 \%$ ).

Table 11 presents the 2018 - percentage of FFP units, and PC therapeutic units issued for clinical purposes following pathogen inactivation.

\section{Wastage of blood and blood components}

In 2018, a total of 102755 units of blood and the most common blood components were wasted, including 14067 units of anticoagulated whole blood, 30521 units of RBCs, 49979 units of fresh frozen plasma (FFP), 1625 therapeutic units of apheresis PC, 5186 PCs from whole blood, and 1376 units of cryoprecipitate.

As in the previous year, the most common reasons for wastage of blood components were:

1. Date expiry.

2. Seropositivity for transfusion transmitted diseases, syphilis, implementation of look-back procedure.

3. Other causes, including:

- Inadequate visual control,

- Low quantity/volume,

- Seropositive serological results,

- other, including incorrect procedures, medical deferral, mechanical damage, donor selfdeferral.

Table 12 presents the number of blood components wasted in individual Centers in 2018; causes of wastage are shown in Table 13. 
Table 8. Leukocyte-depleted and irradiated PC therapeutic doses produced in Polish Regional Blood Transfusion Centers (2018)

\begin{tabular}{|c|c|c|c|c|}
\hline Centers & $\begin{array}{c}\text { PC therapeutic } \\
\text { doses }\end{array}$ & $\begin{array}{l}\text { Leukocyte-depleted } \\
\text { PCs }\end{array}$ & Irradiated PCs & $\begin{array}{l}\text { Both irradiated and } \\
\text { leukocyte-depleted PCs }\end{array}$ \\
\hline Białystok & 4133 & 0 & 0 & 4121 \\
\hline Bydgoszcz & 9063 & 71 & 0 & 8992 \\
\hline Gdańsk & 6202 & 583 & 0 & 5496 \\
\hline Kalisz & 2295 & 2295 & 0 & 0 \\
\hline Katowice & 17128 & 3806 & 0 & 5001 \\
\hline Kielce & 4116 & 834 & 0 & 2084 \\
\hline Kraków & 9191 & 4647 & 3 & 4541 \\
\hline Lublin & 5721 & 206 & 0 & 5477 \\
\hline Łódź & 5420 & 320 & 2 & 5098 \\
\hline Olsztyn & 4490 & 462 & 0 & 3984 \\
\hline Opole & 1570 & 1538 & 0 & 31 \\
\hline Poznań & 14627 & 813 & 1829 & 11205 \\
\hline Racibórz & 1357 & 1335 & 0 & 22 \\
\hline Radom & 1499 & 1295 & 0 & 29 \\
\hline Rzeszów & 7203 & 3425 & 0 & 3778 \\
\hline Słupsk & 1150 & 503 & 0 & 647 \\
\hline Szczecin & 5002 & 3004 & 0 & 1998 \\
\hline Wałbrzych & 1204 & 1204 & 0 & 0 \\
\hline Warszawa & 17127 & 15442 & 0 & 1685 \\
\hline Wrocław & 12625 & 269 & 0 & 12352 \\
\hline ZielonaGóra & 2730 & 1537 & 0 & 1193 \\
\hline Total & 133853 & 43589 & 1834 & 77734 \\
\hline
\end{tabular}

\section{Discussion}

Demand for blood and blood components is steadily growing and is associated with advancement in various fields of medicine as well as such factors as aging of societies. Despite recent attempts at promoting therapies that are alternatives to transfusion of blood and blood components (including patient blood management programs (PBM), the available blood supply still largely depends on the good will of volunteer, non-remunerated blood donors [5-9].

As shown above, in 2018 the number of blood donors in Centers was slightly higher than in 2017 (590 470 and 588184 respectively) which might signal the end of the downward trend observed for the last several years.

One unfavorable phenomenon observed in the recent years is a steady decrease of population in the 18-65 age group — the potential "recruitment source" of blood donors. The Demographic Yearbook reports for December 31, 2011 and December 2018 is - 26464477 and 25264348 respectively $[10,11]$. During the last 7 years the population in this age group has therefore decreased by over a million people, with impact on the number of active blood donors.

In member states of the Council of Europe, the average number of blood donors per 1000 inhabitants decreased from 29.0 in 2008 to 25.0 in 2011 [12]. For Poland the numbers per 1000 inhabitants were 15.37 in 2018 and 15.30 in 2017.

Apart from demographic changes, the number of blood donors is adversely affected by factors such as:

- no opportunity to donate blood or economic reasons;

- periodic disease outbreaks;

- travel-associated risk of infections e.g. malaria or West Nile virus [13]; 
Table 9. FFP units (from whole blood and apheresis) prepared in Polish Regional Blood Transfusion Centers in 2018

\begin{tabular}{|c|c|c|c|c|}
\hline Centers & Whole blood & Apheresis & Total & $\%$ FFP from apheresis \\
\hline Białystok & 59052 & 23299 & 82351 & 28.29 \\
\hline Bydgoszcz & 69264 & 11506 & 80770 & 14.25 \\
\hline Gdańsk & 59531 & 3849 & 63380 & 6.07 \\
\hline Kalisz & 39318 & 24413 & 63731 & 38.31 \\
\hline Katowice & 112737 & 4687 & 117424 & 3.99 \\
\hline Kielce & 33039 & 1997 & 35036 & 5.70 \\
\hline Kraków & 91238 & 98 & 91336 & 0.11 \\
\hline Lublin & 53482 & 11152 & 64634 & 17.25 \\
\hline Łódź & 60633 & 321 & 60954 & 0.53 \\
\hline Olsztyn & 40189 & 3835 & 44024 & 8.71 \\
\hline Opole & 28782 & 137 & 28919 & 0.48 \\
\hline Poznań & 91410 & 9290 & 100700 & 9.22 \\
\hline Racibórz & 31606 & 5219 & 36825 & 14.17 \\
\hline Radom & 21880 & 3890 & 25770 & 15.10 \\
\hline Rzeszów & 60768 & 6252 & 67020 & 9.33 \\
\hline Słupsk & 21965 & 660 & 22625 & 2.92 \\
\hline Szczecin & 50508 & 5363 & 55871 & 9.60 \\
\hline Wałbrzych & 25021 & 0 & 25021 & 0.00 \\
\hline Warszawa & 108332 & 3386 & 111718 & 3.03 \\
\hline Wrocław & 63762 & 23802 & 87564 & 27.18 \\
\hline Zielona Góra & 32441 & 103 & 32544 & 0.32 \\
\hline Total & 1154958 & 143258 & 1298216 & 11.04 \\
\hline
\end{tabular}

- emerging infectious diseases, e.g. the Zika virus epidemics [14-16];

- health condition of the population, including reduced hemoglobin levels (most common cause of deferral for the several last years) [17-20].

The number of autologous donors in 2018 was estimated at 500 which is lower than in 2016 (679) and 2017 (561). The smaller number of preoperative autologous donations is a phenomenon typical for many countries [21]. According to current trends, autologous donations are mostly relied on when they have significant advantage over allogeneic transfusions and when the indication for transfusion is strong [22].

In 2018, the total number of blood and blood component donations amounted to 1264903 including 1184311 whole blood donations; once more there is a slight increase as compared to the previous year (in $2017-1249655$ donations with 1171302 whole blood donations).
One of the methods used for more effective collection of blood components is automated apheresis. In 2018, the number of apheresis PCs donations increased (from 22552 in 2017 to 24587 ), as was the case with PCs and plasma combined (from 16626 to 19 143); on the other hand the number of only plasma donations decreased (from 39084 to 36 655). Collection by apheresis of other blood components, i.e. RBC and granulocyte concentrate was sporadic.

It should be noted that in Poland automated methods (apheresis) are still used to a relatively small extent (in 2018 - only $6.37 \%$ of all donations).

Mobile collections are organized to make blood donation easier for donors. In 2018 the number of mobile collection sites organized by the Centers did not change as compared to 2017 (13 189). The percentage of whole blood donated during mobile collections has been steadily growing since 2016, and is now relatively stable (26-29\%). In 2018, as in the previous years, blood 
Table 10. FFP units issued for clinical use in Polish Regional Blood Transfusion Centers (2018)

\begin{tabular}{|c|c|c|c|}
\hline Centers & Prepared & $\begin{array}{l}\text { Issued for } \\
\text { clinical use }\end{array}$ & $\begin{array}{l}\% \text { FFP is- } \\
\text { sued for } \\
\text { clinical use }\end{array}$ \\
\hline Białystok & 82351 & 12131 & 14.73 \\
\hline Bydgoszcz & 80770 & 17082 & 21.15 \\
\hline Gdańsk & 63380 & 11426 & 18.03 \\
\hline Kalisz & 63731 & 4346 & 6.82 \\
\hline Katowice & 117424 & 26991 & 22.99 \\
\hline Kielce & 35036 & 6921 & 19.75 \\
\hline Kraków & 91336 & 23141 & 25.34 \\
\hline Lublin & 64634 & 16205 & 25.07 \\
\hline Łódź & 60954 & 18090 & 29.68 \\
\hline Olsztyn & 44024 & 9055 & 20.57 \\
\hline Opole & 28919 & 4840 & 16.74 \\
\hline Poznań & 100700 & 17692 & 17.57 \\
\hline Racibórz & 36825 & 2712 & 7.36 \\
\hline Radom & 25770 & 3173 & 12.31 \\
\hline Rzeszów & 67020 & 10831 & 16.16 \\
\hline Słupsk & 22625 & 3018 & 13.34 \\
\hline Szczecin & 55871 & 15846 & 28.36 \\
\hline Wałbrzych & 25021 & 5079 & 20.30 \\
\hline Warszawa & 111718 & 45222 & 40.48 \\
\hline Wrocław & 87564 & 12310 & 14.06 \\
\hline $\begin{array}{l}\text { Zielona } \\
\text { Góra }\end{array}$ & 32544 & 5593 & 17.19 \\
\hline Total & 1298216 & 271702 & 20.93 \\
\hline
\end{tabular}

was mainly collected at local collection sites $(44.85 \%)$ which may be explained by the fact that donors are more willing to donate in familiar places. However, the contemporary high standards for collection of blood dedicated for clinical use do not favor small collection sites; centralization of blood transfusion service is recommended.

The demand for blood components depends on numerous factors such as: profile of the clinical ward, current guidelines issued by scientific societies, recommendations of the physician and last but not least - economic factors.

In 2018, approximately 30.38 units of $\mathrm{RBC}$ per 1000 inhabitants were issued for clinical purposes (in $2017-30.22$ units, $2016-29.99,2015-$ 29.87) [11,23-25]. The differences observed in the past several years are insignificant but the upward trend is observed. RBC consumption however is
Table 11. Pathogen inactivated FFP (\%), cryoprecipitate (\%) and PCs (\%) issued for clinical use in 2018

\begin{tabular}{lccc}
\hline Centers & $\begin{array}{c}\text { \% FFP } \\
\text { (U.) }\end{array}$ & $\begin{array}{c}\text { \% cryopre- } \\
\text { cipitate } \\
\text { (U.) }\end{array}$ & $\begin{array}{c}\text { \% PCs } \\
\text { (therapeutic } \\
\text { doses) }\end{array}$ \\
\hline Białystok & 12.13 & 0 & 0.10 \\
Bydgoszcz & 5.07 & 0 & 0.00 \\
Gdańsk & 1.91 & 0 & 0.00 \\
Kalisz & 0.00 & 0 & 0.00 \\
Katowice & 5.74 & 0 & 0.00 \\
Kielce & 0.00 & 0 & 0.00 \\
Kraków & 18.79 & 0 & 0.00 \\
Lublin & 2.87 & 100 & 2.09 \\
Łódź & 6.15 & 0 & 1.27 \\
Olsztyn & 0.00 & 0 & 0.00 \\
Opole & 0.00 & 0 & 0.00 \\
Poznań & 7.77 & 98.07 & 0.00 \\
Racibórz & 5.13 & 0 & 0.00 \\
Radom & 0.00 & 0 & 0.00 \\
Rzeszów & 7.65 & 0 & 0.00 \\
Słupsk & 0.00 & 0 & 0.00 \\
Szczecin & 0.00 & 0 & 0.00 \\
Wałbrzych & 0.00 & 0 & 0.00 \\
Warszawa & 27.19 & 0 & 97.11 \\
Wrocław & 25.37 & 0 & 1.84 \\
Zielona Góra & 0.00 & 0 & 0.00 \\
Total & 10.23 & 18.52 & 11.74 \\
\hline & & & \\
& 0.00 & 0 \\
\hline
\end{tabular}

still markedly lower than in some other European countries; in 2011, the consumption of RBC in 32 member states of the Council of Europe was on average 37 units/1000 inhabitants [12].

In 2018 the number of FFP units issued for clinical purposes amounted to 271702 and was again lower than in the preceding year $(2017$ - 291989 units). In 2018, the ratio of RBC for clinical use to FFP was approximately 4.09 (in $2017-3.77$, in $2016-3.56$, in $2015-3.45$ ). The consumption of FFP gradually decreases as compared to red blood cells. The RBC/FFP ratio is however still lower than in many other European countries [12]. This may be explained by lower consumption of $\mathrm{RBC}$ in Poland but in many cases also by the fact that FFP is used with no sufficient reason and sometimes against current indications [26, 27].

As already mentioned the last several years have witnessed an increase in the consumption of PC. In the period 2015-2018 the number of PC units issued for clinical use has increased by about $11 \%$. 
Table 12. Wastage of blood components in Polish Regional Blood Transfusion Centers (2018)

\begin{tabular}{|c|c|c|c|c|c|}
\hline & \multirow[t]{2}{*}{ Whole blood } & \multirow[t]{2}{*}{ RBCs } & \multicolumn{2}{|c|}{ PCs (therapeutic doses) } & \multirow[t]{2}{*}{ FFP } \\
\hline & & & $\begin{array}{l}\text { Pooled from } \\
\text { whole blood }\end{array}$ & Apheresis & \\
\hline Białystok & 296 & 628 & 30 & 29 & 1171 \\
\hline Bydgoszcz & 511 & 531 & 195 & 18 & 3364 \\
\hline Gdańsk & 454 & 1381 & 402 & 12 & 1932 \\
\hline Kalisz & 71 & 1758 & 139 & 11 & 1223 \\
\hline Katowice & 1496 & 3127 & 534 & 173 & 2222 \\
\hline Kielcach & 77 & 806 & 494 & 26 & 1389 \\
\hline Kraków & 536 & 1510 & 168 & 33 & 8137 \\
\hline Lublin & 664 & 1497 & 130 & 76 & 3048 \\
\hline Łódź & 1008 & 2428 & 219 & 48 & 3527 \\
\hline Olsztyn & 152 & 2127 & 225 & 52 & 1295 \\
\hline Opole & 134 & 485 & 45 & 11 & 1211 \\
\hline Poznań & 1530 & 2967 & 765 & 102 & 3009 \\
\hline Racibórz & 147 & 281 & 66 & 32 & 758 \\
\hline Radom & 286 & 744 & 185 & 36 & 889 \\
\hline Rzeszów & 2895 & 1713 & 582 & 47 & 1441 \\
\hline Słupsk & 220 & 313 & 0 & 4 & 334 \\
\hline Szczecin & 151,3 & 1656 & 177 & 146 & 2974 \\
\hline Wałbrzych & 283 & 789 & 32 & 6 & 277 \\
\hline Warszawa & 1820 & 2930 & 238 & 592 & 8509 \\
\hline Wrocław & 953 & 1859 & 163 & 169 & 2440 \\
\hline Zielona Góra & 383 & 991 & 397 & 2 & 832 \\
\hline Total & 14067 & 30521 & 5186 & 1625 & 49979 \\
\hline
\end{tabular}

Additional preparation methods (leukocyte depletion, irradiation) for prevention of transfusion associated adverse reactions were applied much more frequently to PCs $(32.56 \%$ leukocyte depleted PCs, $1.37 \%$ irradiated PCs and $58.07 \%$ irradiated leukocyte depleted PCs) than to RBC (17.29\% leukocyte depleted, $0.31 \%$ irradiated and 8.94\% leukocyte depleted and irradiated). Leukocyte depleted $\mathrm{RBC}$ require additional preparation, while in the case of PCs from apheresis, leukodepletion may occur at collection. Some automated methods of PC preparation from buffy coat also allow leukodepletion but the cost is high as compared to manual methods. Automated methods do however guarantee high quality parameters due to standardization.

Currently, most Centers prepare almost exclusively leukocyte depleted PCs (Table 8). As mentioned above, leukocyte-depleted PCs account for about $90.64 \%$ of all PCs obtained country-wide. In many countries regular/common leuko-depletion is currently used although its effectiveness in preventing transfusion-related adverse reactions is sometimes questioned [28].

As in the previous years, the number of frozen $\mathrm{PCs}$ in some Centers is too high. As mentioned earlier, in 2018 there was a decrease by $0,9 \%$ as compared to 2017. The percentage reported for the whole country is acceptable. It must be noted however, that routine freezing of large volumes of blood components - eg. pooled PCs in Racibórz $(75,2 \%)$ - is not to be accepted. Thawed PCs may be used only in special circumstances, therefore it is not recommended to freeze more than $10 \%$. This does not refer to freezing of apheresis PCs collected from patients with anti-HLA or anti-HPA antibodies.

It is worth noting that freezing and thawing adversely affects quality parameters of platelets and so their therapeutic efficacy. It follows from 
Table 13. Reasons for blood component wastage in Polish Regional Blood Transfusion Centers (2018)

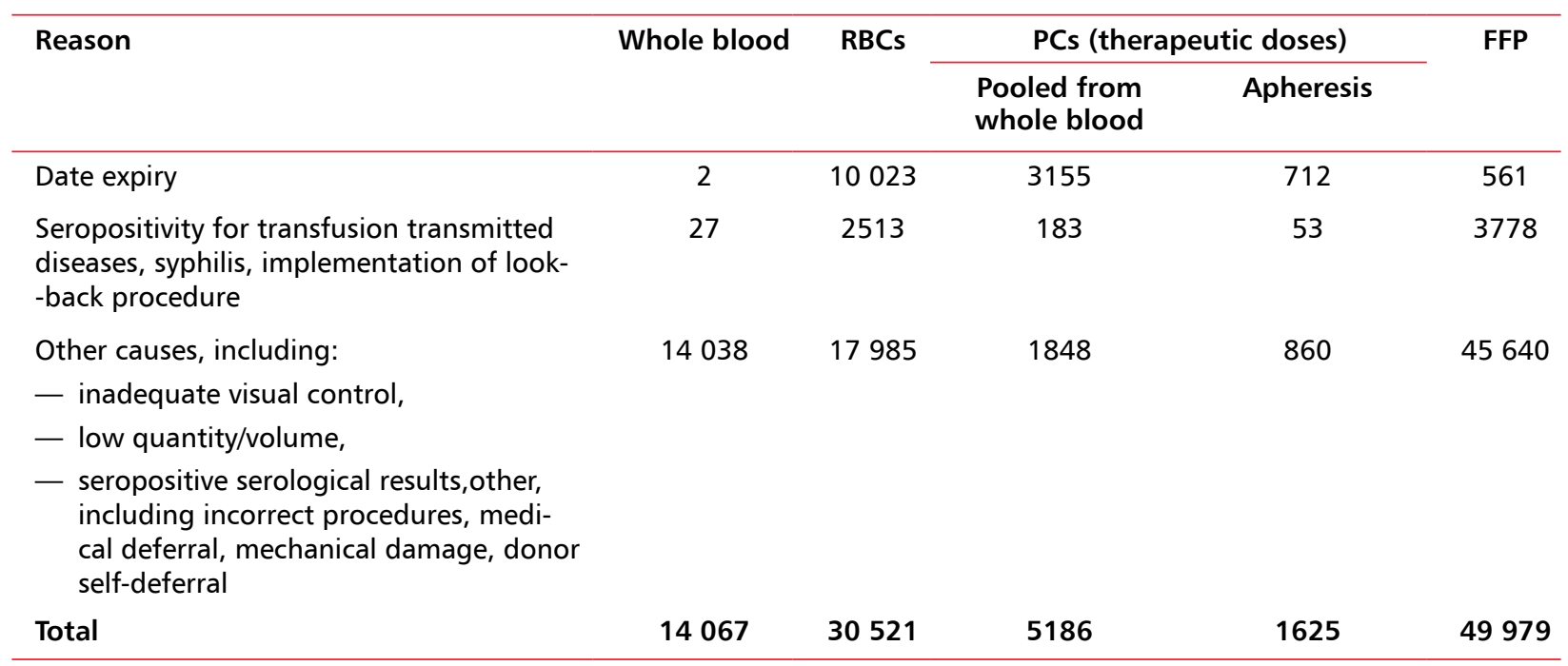

the 2018 data that the situation has improved, especially in Wałbrzych, where the amount of thawed PCs for clinical use has decreased by $11,3 \%$ as compared to 2017.

Depletion of blood and blood component supplies is also associated with wastage which though sometimes inevitable - occurs for a number of reasons. In 2018 (as in previous years) the most common causes of wastage were the so-called "other reasons", in particular:

- inadequate visual control;

— incorrect/low volume;

- seropositive test results;

- incorrect procedures, medical deferral, mechanical damage, donor self-deferral, etc.

Most probably some waste could be avoided by better adherence to procedures [29].

Date expiry or positive results of viral tests were less frequently the reason for waste (Table 13).

Data related to quarantine and pathogen inactivated FFP and cryoprecipitate revealed that quarantine FFP is still most commonly used in clinical practice. As in the previous years, most Centers did not make adequate use of the illuminators installed on their premises (Mirasol PRT system - 28illuminators, TheraflexMB Plasma system - 12 illuminators, Intercept system 1 illuminator). The most likely reason is that physicians rarely order pathogen inactivated FFP, and PCs. One reason for limited use of pathogen inactivated plasma is the easy access to quarantine FFP. On the other hand, physicians who order components are not always fully aware that pathogen inactivated plasma is much safer than quarantine plasma; it protects against the consequences of the "diagnostic window" (as is the case with quarantine plasma) but also prevents the transmission of a wide spectrum of pathogens.

Study results demonstrated that both the Mirasol and Intercept PRT systems reduce the number of viable T lymphocytes in PCs ( $>6 \mathrm{log}$ and $>5.4 \mathrm{log}$, respectively) [4]. Further research confirmed these systems to be an alternative to irradiation of cellular blood components so far used for prevention of TA-GvHD in high risk patients [2].

Physicians who are not always aware that pathogen inactivation is an alternative to irradiation of cellular blood components often order PCs subjected both to pathogen inactivation (in one of the above mentioned systems) and irradiated. The procedure is incorrect because the use of both gamma irradiation and inactivation may induce platelet activation, which contributes to faster removal of platelets from the recipient's circulatory system [30].

This suggests that the number of training courses for physicians on pathogen inactivation and strengthening of blood safety is still not sufficient.

\section{Conclusions}

The study is a brief presentation of selected issues related to the activity of Polish Regional Blood Transfusion Centers in 2018, as well as to some recently observed tendencies which may be a good starting point for analysis of issues related to the activity of healthcare units in Polish BTS, for comparison of experiences and development of optimal solutions for the future. Such data reviews 
on blood and blood components are systematically performed in other countries.

\section{Current problems of blood transfusion medicine}

In light of available data, the worldwide number of blood transfusions is still too high and excessively exploited despite intensive campaigns and appeals for rational blood therapy and spectacular successes of some countries which implemented the PBM programs [31].

In the United States in 2011, blood transfusion was the most common procedure performed during hospitalization (12\% of surgeries), and since 1997 the number of hospitalizations with surgery has more than doubled [32]. In Poland the number of red blood cell units issued for clinical use has been stable for the last several years, while the number of PCs is steadily growing [33-35].

Higher demand for PCs is also observed in other countries. Great Britain is one such country [36]. The greatest PC consumers are:

- patients with hematologic malignancies (67\%);

- cardio surgical patients (up to $10 \%$ );

- intensive therapy patients $(8 \%)$.

Higher demand for PCs is determined by the following factors: overall population increase, aging of societies, higher incidence rate of hematologic malignancies and modifications in the therapy of myeloproliferative disorders. However, the only available data that can be directly compared between countries refers to overall population. There seems to be no evidence that the increase in PC transfusions in cardio surgical or intensive therapy patients is higher than that determined by overall population growth. Data on the issue are scarce [36].

In 2005 the patient blood management (PBM) program was developed which shifted the attention from transfusion of allogenic blood to that of the patient's. As already signaled in earlier publications, the program was supported by numerous organizations including WHO and European Commission as well as by research and expert societies [33-35]. Within the new approach to transfusion therapy the PBM principles are indisputable, the methods of their implementation at hospital level are however open to discussion. European institutions devote much time to analysis of PBM implementation and in March 2017 published a guide "Supporting Patient Blood Management (PBM) in EU. A practical implementation guide for hospitals" [37]. In this publication attention is focused on the following indicators of blood use:
- transfusion rate (TR) i.e. number of transfused patients in a defined cohort;

- transfusion index (TI) i.e. average number of $\mathrm{RBC}$ units transfused per patient in a defined cohort.

The values help to determine the degree of PBM implementation in a hospital; the higher the values, the lesser degree of PBM use. The next step (in PBM implementation) is collection of data on anemia frequency and methods of treatment. A still further step is collection of data on perioperative blood loss. The final step is the comparison of treatment outcome for patients transfused according to PBM and for those who were not.

An exceptionally interesting world-wide initiative for implementation of PBM are the Consensus Conferences. They are not only examples of a restrictive and transparent scientific process but also contribute a unique value of promoting international cooperation. The participants represent European, American, Canadian and Australian organizations which focus attention on principles of transfusion medicine and PBM promotion. During the last, 2018 Consensus Conference in Frankfurt, international experts addressed an interdisciplinary panel with a set of evidence-based recommendations for PBM and research rated according to GRADE (Grades of Recommendation, Assessment, Development and Evaluation) [38]. The issues discussed during the conference referred to:

- hemoglobin $(\mathrm{Hb})$ threshold for $\mathrm{RBC}$ transfusion;

- preoperative anemia;

- education and training in the implementation of PBM principles.

The analysis presented during the Conference included the outcome of 63 random clinical trials (23 143 patients) and 82 observation studies ( more than 4 million patients). The current data base for PBM evidence for scientific and practical purposes was defined and 10 clinical indications as well as 12 recommendations were suggested. One of the significant recommendations of the Conference referred to the management of preoperative anemia. Four (4) clinical and 3 research recommendations were developed including one explicit recommendation - namely, to identify and treat anemia in due time before surgery.

\section{Acknowledgements}

The Authors express their thanks to the National Blood Center and the Regional Blood Transfusion Centers for access to the relevant information and for support in the analysis of forwarded data. 


\section{References}

1. Ustawa $z$ dnia 22 sierpnia 1997 r. o publicznej służbie krwi (Dz. U. Nr 106, poz. 681 z późn. zmian.).

2. Osselaer JC, Cazenave JP, Lambermont M, et al. An active haemovigilance programme characterizing the safety profile of 7437 platelet transfusions prepared with amotosalen photochemical treatment. Vox Sang. 2008; 94(4): 315-323, doi: 10.1111/j.1423-0410.2007.01035.x, indexed in Pubmed: 18248574.

3. Schlenke P. Pathogen inactivation technologies for cellular blood components: an update. Transfus Med Hemother. 2014; 41(4): 309-325, doi: 10.1159/000365646, indexed in Pubmed: 25254027.

4. Grass JA, Wafa T, Reames A, et al. Prevention of transfusion-associated graft-versus-host disease by photochemical treatment. Blood. 1999; 93(9): 3140-3147, indexed in Pubmed: 10216113.

5. Farmer SL, Trentino K, Hofmann AA. Programmatic Approach to Patient Blood Management - Reducing Transfusions and Improving Patient Outcome. The Open Anesthesiology Journal. 2015; 9: 6-16.

6. van Hoeven LR, Koopman MMW, Koffijberg H, et al. Historical time trends in red blood cell usage in the Netherlands. International Journal of Clinical Transfusion Medicine. 2016; 4: 67-77.

7. Ellingson KD, Sapiano MRP, Haass KA, et al. Continued decline in blood collection and transfusion in the United States-2015. Transfusion. 2017; 57 Suppl 2: 1588-1598, doi: 10.1111/trf.14165, indexed in Pubmed: 28591469.

8. WHO Expert Group. Expert Consensus Statement on achieving self-sufficiency in safe blood and blood products, based on voluntary non-remunerated blood donation (VNRBD). Vox Sang. 2012; 103(4): 337-342, doi: 10.1111/j.1423-0410.2012.01630.x, indexed in Pubmed: 22690746.

9. World Health Organization. Towards Self-Sufficiency in Safe Blood and Blood Products based on Voluntary Non-Remunerated Donation. Global Status 2013.

10. Główny Urząd Statystyczny, Komitet Redakcyjny. Rocznik demograficzny 2012.

11. Komitet Redakcyjny Głównego Urzędu Statystycznego. Rocznik demograficzny 2019.

12. Pogłód R, Rosiek A, Grabarczyk P, et al. Charakterystyka podstawowych wskaźników dotyczących krwiodawstwa i krwiolecznictwa w Europie - aktualne wyzwania i działania. Journal of Transfusion Medicine. 2015; 8(2): 60-77.

13. Rabel PO, Planitzer CB, Farcet MR, et al. Increasing West Nile virus antibody titres in central European plasma donors from 2006 to 2010. Euro Surveill. 2011; 16(10), doi: 10.2807/ ese.16.10.19812-en, indexed in Pubmed: 21435324.

14. Stramer SL, Hollinger FB, Katz LM, et al. Emerging infectious disease agents and their potential threat to transfusion safety. Transfusion. 2009; 49 Suppl 2: 1S-29S, doi: 10.1111/j.1537-2995.2009.02279.x, indexed in Pubmed: 19686562.

15. Musso D, Nilles EJ, Cao-Lormeau VM. Rapid spread of emerging Zika virus in the Pacific area. Clin Microbiol Infect. 2014; 20(10): O595-0596, doi: 10.1111/1469-0691.12707, indexed in Pubmed: 24909208.

16. Jimenez A, Shaz BH, Bloch EM. Zika Virus and the Blood Supply: What Do We Know? Transfus Med Rev. 2017; 31(1): 1-10, doi: 10.1016/j.tmrv.2016.08.001, indexed in Pubmed: 27569055.

17. Rosiek A, Dzieciątkowska A, Lachert E, et al. Obniżone stężenie hemoglobiny jako przyczyna dyskwalifikacji dawców na terenie Polski. Journal of Transfusion Medicine. 2009; 2(2): 73-78.
18. Rosiek A, Tomaszewska A, Lachert E, et al. Obniżone stężenie hemoglobiny najczęstszą przyczyną dyskwalifikacji krwiodawców na terenie Polski. Acta Haematologica Polonica. 2015; 46(Suppl.1): 24.

19. Goldman M, Magnussen K, Gorlin J, et al. International Forum regarding practices related to donor haemoglobin and iron. Vox Sang. 2016; 111(4): 449-455, doi: 10.1111/vox.12431, indexed in Pubmed: 27564140.

20. Vuk T, Magnussen K, De Kort W, et al. International forum: an investigation of iron status in blood donors. Blood Transfus. 2017; 15(1): 20-41, doi: 10.2450/2016.0101-16, indexed in Pubmed: 27643753.

21. Vassallo R, Goldman M, Germain M, et al. BEST Collaborative. Preoperative Autologous Blood Donation: Waning Indications in an Era of Improved Blood Safety. Transfus Med Rev. 2015; 29(4): 268-275, doi: 10.1016/j.tmrv.2015.04.001, indexed in Pubmed: 26006319 .

22. European Directorate for the Quality of Medicines and HealthCare (EDQM). Guide to the preparation, use and quality assurance of blood components: recommendation No. R (95) 15, wyd. 19, 2017.

23. Główny Urząd Statystyczny, Komitet Redakcyjny. Rocznik demograficzny 2017.

24. Główny Urząd Statystyczny, Komitet Redakcyjny. Rocznik demograficzny 2015.

25. Główny Urząd Statystyczny, Komitet Redakcyjny. Rocznik demograficzny 2016.

26. NICE. Blood transfusion. NICE guideline. Published: 18 November 2015. nice.org.uk/guidance/ng24 [Online].

27. Klein AA, Arnold P, Bingham RM, et al. AAGBI guidelines: the use of blood components and their alternatives 2016. Anaesthesia. 2016; 71(7): 829-842, doi: 10.1111/anae.13489, indexed in Pubmed: 27062274.

28. Simancas-Racines D, Osorio D, Martí-Carvajal AJ, et al. Leukoreduction for the prevention of adverse reactions from allogeneic blood transfusion. Cochrane Database Syst Rev. 2015(12): CD009745, doi: 10.1002/14651858.CD009745.pub2, indexed in Pubmed: 26633306.

29. Heitmiller ES, Hill RB, Marshall CE, et al. Blood wastage reduction using Lean Sigma methodology. Transfusion. 2010; 50(9): 1887-1896, doi: 10.1111/j.1537-2995.2010.02679.x, indexed in Pubmed: 20456700.

30. Apelseth TØ, Bruserud $\varnothing$, Wentzel-Larsen T, et al. In vitro evaluation of metabolic changes and residual platelet responsiveness in photochemical treated and gamma-irradiated single-donor platelet concentrates during long-term storage. Transfusion. 2007; 47(4): 653-665, doi: 10.1111/j.1537-2995.2007.01167.x, indexed in Pubmed: 17381624.

31. Zeller MP, Kaufman RM. Safeguarding the Patient's Own Blood Supply. JAMA. 2019; 321(10): 943-945, doi: 10.1001/ jama.2019.0553, indexed in Pubmed: 30860548.

32. Pfuntner A, Wier LM, Stocks C. Most Frequent Procedures Performed in U.S. Hospitals, 2011. https://www.hcup-us.ahrq. gov/reports/statbriefs/sb165.jsp [online].

33. Rosiek A, Tomaszewska A, Lachert E, et al. Działalność jednostek organizacyjnych służby krwi w Polsce w 2015 roku. Journal of Transfusion Medicine 2016 (9). ; 4: 1-18.

34. Rosiek A, Tomaszewska A, Lachert E, et al. Działalność jednostek organizacyjnych służby krwi w Polsce w 2016 roku. Journal of Transfusion Medicine. 2017; 10(4): 113-129. 
35. Rosiek A, Tomaszewska A, Lachert E, et al. Działalność jednostek organizacyjnych służby krwi w Polsce w 2017 roku. Journal of Transfusion Medicine, 2018 (11)4, 113 - 130.

36. Estcourt LJ. Why has demand for platelet components increased? A review. Transfus Med. 2014; 24(5): 260-268, doi: 10.1111/ tme.12155, indexed in Pubmed: 25327286.

37. Gombotz H, Kastner P, Nørgaard A, et al. Supporting Patient Blood Management (PBM) in the EU. A practical implementation guide for hospitals. https://ec.europa.eu/health/sites/health/ files/blood_tissues_organs/docs/2017_eupbm_hospitals_en. pdf [online].

38. Mueller MM, Van Remoortel H, Meybohm P, et al. ICC PBM Frankfurt 2018 Group. Patient Blood Management: Recommendations From the 2018 Frankfurt Consensus Conference. JAMA. 2019; 321(10): 983-997, doi: 10.1001/ jama.2019.0554, indexed in Pubmed: 30860564. 